Snežana Knežević ${ }^{1}$, Predrag Jovanović ${ }^{2}$, Aleksandra Mitrovićc ${ }^{3}$

1 University of Belgrade, Faculty of Organizational Sciences, Serbia

2 Public Procurement Office, Republic of Serbia

${ }^{3}$ University of Kragujevac, Faculty of Hotel Management and Tourism, Serbia

\title{
Fiscal Decentralization - City of Belgrade Case Study
}

UDC: $336.14: 352(497.11$ Beograd)"2013/2015"

DOI: 10.7595/management.fon.2016.0015

\begin{abstract}
The research in this paper is devoted to analysis of budget items for the city of Belgrade, to revenues and earnings, expenses and issuance for 2013, 2014 and 2015 in order to determine changes in the structure and in time, and, based on these, the appropriate conclusions were drawn, which can serve as recommendations for creating budgets in the future.

One of the key problems in public procurement at the City of Belgrade level were significant differences in prices for the same items procured by different contracting authorities. In many cases the same bidder offered the very same items at prices which differed up to $50 \%$ to different contracting authorities at the city level. That was a signal for the city administration to centralize the procurement of certain items in 2015 achieving significant reduction in prices of bundled procurement compared to the ones undertaken by different contracting authorities previously. In this context, the subject of the second part of this paper will be devoted to the importance of centralization of public procurements in the segment where it is possible to achieve efficiency in the management of budget funds.
\end{abstract}

Keywords: fiscal decentralization, expenditures, revenues, local governments, public procurements

\section{Introduction}

Within the EU, the process of the public sector reform has intensified upon the dawn of the economic crisis, generating a necessity to fulfill the citizens' needs at the same or at a higher level but this time with limited or reduced funds. This resulted in putting the matter of public sector's cost-effectiveness and efficiency at the forefront, and the perception of public sector's capability to achieve these goals by taking its cue from the private sector (Jovanović 2015). A new concept was introduced, Total Quality Management (TQM), one that presumes orientation towards the users of services, measuring the performance of services provided under reduced expenditures (Erridge, Fee \& Mcllroy, 1998).

The starting point of this approach was that the private sector was more efficient than the public one, and that the changes in the public sector - that would place the latter's executive in the conditions more comparable to those in place for the private companies and their management - would have the same result: an increased efficiency in meeting the needs of beneficiaries (citizens) as reflected in higher standards of services provided at the same or at lower costs (Self, 1993). For the executives in state bodies, the performance of provided services becomes a priority; in parallel, they are entrusted with the governing and financial responsibility, and this means decentralization.

However, a high level of decentralization does not automatically translate into a higher efficiency and costeffectiveness in the work of public administration, including accomplishing the tasks related to public procurement. Moreover, high decentralization in public procurement which often goes hand in hand with smaller values of procurement, may result in focusing on the process itself and formal compliance while neglecting cost-effectiveness and efficiency (McCue \& Pitzer, 2000).

In considering the matter of centralization, the attention should not be reduced to integration of public procurement procedures and achievement of savings for "bulk buying" only, as it is usually the case. Such ap- 
proach typically neglects potential benefits to public procurement that may result from establishing a special body in charge of public procurement, which becomes a "centre of expertise" in the area of public procurement, prepares tender documentation for specific procurement subjects that serve as the standard to other contracting authorities, provides expert assistance to contracting authorities at the local level, and monitors and controls the procedures. In addition to ensuring cost-effectiveness, efficiency and compliance, this centralized body plays an important role in achieving some other strategic goals of local self-governments, too, such as: stimulating local economic development, innovation, promoting "green" procurements, socially responsible procurements, raising quality standards in procurement, etc. (Schapper, Malta \& Gilbert, 2006).

Before we move on to the presentation of the practice and the effects of centralization in public procurement at the level of the City of Belgrade, we deem it useful to insert a general overview of the effect of centralization on transaction costs, having in mind that the effect of centralization is viewed primarily through the lens of its effect on purchase price on the basis of „bulk buying" and the buyer's favourable market position relative to the suppliers, originating from the "aggregation" of demand, whereas the influence of centralization on transaction costs often remains overlooked.

Transaction costs may be defined as costs related to the activity that need to be performed to transfer a specific product or service from one organizational system into another (Jaško, Čudanov, Jevtić \& Krivokapić, 2013), and in case of public procurement, from bidder to contracting authority (Jaško, Jovanović \& Čudanov, 2015).

Transaction costs may be subdivided into four categories: 1) costs of research, 2) costs of contracting, 3) costs of monitoring, and 4) costs of implementation. (Williamson, 1985; Hennart, 1993; North, 1990). Costs of research include the costs of collecting market-related information on supply, competition, etc. Costs of contracting include the costs of the procedures of drafting and of awarding the contract. Costs of monitoring are the costs related to monitoring whether both contracting parties fulfill their contractual obligations, whereas the costs of implementation include the costs of litigation and of sanctioning the defaulting contracting party (Dyer,1997).

Centralized public procurement bodies (CPPB) conduct procedures for the conclusion of framework agreements defining the price for the required procurement subject. On the basis of framework agreements, end beneficiaries conclude individual contracts with the supplier. Thus, several procurement procedures, which would have otherwise been conducted by several contracting authorities individually, are substituted here by a single procedure conducted by a CPPB. This translates into savings in the first two categories of transaction costs (costs of research and costs of contracting), whereas the last two categories of costs (costs of monitoring and costs of implementation) are borne by contracting authority since it concludes the contract, monitors its implementation and undertakes compensation related activities in the cases of deviation from the contracted features, quality, quantity, timelines, including measures for sanctioning suppliers over the violations of contractual obligations.

Transaction costs also arise where a request for the protection of rights is filed because a party entitled to lodge such request did so in belief that tender documentation was discriminatory or that the regularity of the procedure had been violated. Having in mind that the contracting authority may not award the contract until the body tasked with the protection of rights decides whether the complaint is founded or not, the transaction costs are directly proportional to the duration of the procedure for the protection of rights.

In addition, cancellation of a procurement procedure due to irregularities made by contracting authority means that the procedure has to be repeated, thus increasing transaction costs both of contracting authority and bidders. Therefore, competence and efficiency of the party conducting public procurement is vital to the level of transaction cost.

\section{Department for Centralized Public Procurement and Procurement Control of the City of Belgrade}

The Department for Centralized Public Procurement and Procurement Control of the City of Belgrade was established for the purpose of conducting centralized public procurements for contracting authorities whose founder is the City of Belgrade. 
In 2015, the Department conducted public procurements for the following procurement subjects: computers (for 23 contracting authorities), motor fuels for motor vehicles (for 22 contracting authorities), energy products - gas oil and heating oil (for 4 contracting authorities), Microsoft licence (for 2 contracting authorities), processed meat products and cured meat products (for 5 contracting authorities), frozen fruit and frozen vegetables (for 2 contracting authorities), frozen fish (for 4 contracting authorities), hygiene items (for 35 contracting authorities), hygiene tools and equipment (for 32 contracting authorities), paper products for personal hygiene (for 34 contracting authorities), office stationery and supplies (for 48 contracting authorities) and mobile telephony services (for 14 contracting authorities). Data on the number of contracting authorities (end-users) for whom the Department has conducted procedures, by procurement subjects, indicate that the Department conducted centralized procurement, on average, for 19 contracting authorities.

In addition to conducting centralized public procurements, the Department also controls procurements conducted by contracting authorities whose founder is the City. Concretely, in 2015, the Department checked the need proposals of 14 contracting authorities and draft procurement plans of 23 contracting authorities. Further, it reviewed 688 documents issued in public procurement procedures by the organizational units of the City of Belgrade. From the compliance aspect, the most important are proposals for tender documentation (232 proposals reviewed), and in particular the technical specifications (174 proposals reviewed), and decisions on awarding contracts (155 proposals reviewed) since all these, as a rule, may be challenged by the request for the protection of rights which augment transaction costs and entail additional risks of having to repeat the procedure.

In 2014, when contracting authorities have been conducting their own public procurement procedures, there were 35 requests for the protection of rights, out of which 7 challenged tender documentation, and the remaining 28 challenged expert evaluation of bids, whereas in 2015 , when the Department has not only performed the function of conducting public procurement in the centralized manner for the sake of several contracting authorities, but also played a preventive role in checking the key documents in public procurement procedures conducted individually by contracting authorities, the number of requests for the protection of rights was considerably reduced. Thus, in 2015 there were 14 requests in total, out of which 4 challenging tender documentation and 10 challenging expert evaluation of bids. This clearly demonstrates significance of the preventive role of the Department in reducing the risk of the protection of rights and cancelation of the procedures, thus also considerably reducing a potential transaction cost.

\section{Effects of Centralization on Purchase Prices}

The findings of the analysis of procurements conducted for the needs of the City administrative bodies in 2014, revealed these two features (Analysis of public procurements conducted by the bodies of City administration of the City of Belgrade in 2014):

- Firstly, there exist significant differences in prices at which contracting authorities in the territory of the City of Belgrade procure the same goods, and

- Secondly, the same suppliers have, quite often, sold the same goods to contracting authorities in the territory of the City at different prices.

The following examples from the practice offer a more detailed insight into the above statements:

- In relation to the procurement of office supplies, it was observed that the difference in prices between the cheapest procurement of folders of RSD 9 apiece and the most expensive one of RSD 14 apiece, having the same features and coming from the same supplier, was $55 \%$. In addition, a single supplier has been supplying PVC foils of the same characteristics to the contracting authorities in the territory of the City at prices differing one from another at the scale of up to $120 \%$; on top of that, the prices at which contracting authorities made purchases from this supplier varied significantly - from $25 \%$ upwards. It was also observed that one contracting authority paid for the staplers 1.7 times a higher price than another, whereas the differences in purchase prices paid by two other contracting authorities in relation to the lowest and the highest prices also proved to be rather substantial (60\% in relation to the lowest, and $70 \%$ in relation to the highest price).

- When it comes to the procurement of hygiene items, it was observed that the difference in prices at which one supplier had supplied the City utilities with detergent for machine washing of clothes amounted up to $60 \%$; further, a public utility has paid 1.5 more for the supply of detergent for hand washing of dishes than another one. In this range, the differences among the purchase prices paid by individual contracting authorities were quite considerable, ranging from $25 \%$ upwards. 
- When considering public procurement that procured food articles, it was observed that in 2014 one supplier had supplied the preschools in the territory of the City with milk of standardized characteristics and packaging at prices that differed up to $21 \%$, and that this same supplier managed to attain even greater discrepancies when supplying preschools with yogurt of standardized characteristics and packaging, so that relevant purchase prices differed by as much as $31 \%$. It was also observed that the differences in prices in the supplying of preschools with sour cream by that same supplier reached $24 \%$.

The above elaborated examples reveal significant differences in the prices at which the same suppliers used to sell the identical goods to bodies, institutions and public utilities at the level of the City. Taken from this aspect, the centralization of procurements that paves the way for equalization of prices for contracting authorities founded by the City, is fully justified. In addition, it is also worth an effort to understand whether the centralization of public procurements had any effect to the actual sum of purchase prices. This can be concluded by comparing the prices at which the contracting authorities have individually bought respective subjects of procurement, with the prices achieved by the Department for Centralized Public Procurement in aggregating quantities for several contracting authorities for the same subjects of procurement. According to the data from the analysis performed by the Department for Centralized Public Procurement (Analysis of public procurements conducted by the bodies of City administration of the City of Belgrade in 2014), in 2015 savings were achieved in the mentioned 12 centralized public procurements, on the grounds of lower purchase prices relative to the projected ones, in the total of some EUR 2 million. As the basis for the projected prices were taken purchase prices from the previous year (2014) at which contracting authorities had procured given subjects, and where the subjects of procurement had not been procured in that previous year, market prices were taken instead, reduced for $30 \%$ of the margin that suppliers typically grant for large quantities, such as is the case with consolidated procurements.

Table 1 shows data for four procurements: services of mobile telephony, which achieved the largest single savings of some EUR 480,000, and three other procurements, where the public procurement analysis (Analysis of public procurements conducted by the bodies of City administration of the City of Belgrade in 2014) established existence of substantial differences in prices: food articles, hygiene items, and office supplies.

Table 1: Savings accrued from lower prices attained in centralized procurements in 2015, in comparison with individual procurements of the same products in 2014

\begin{tabular}{|l|l|}
\hline Name of category/subject of procurement & Savings (in \%) \\
\hline Hygiene items & $46 \%$ \\
\hline Services of mobile telephony & $53 \%$ \\
\hline Frozen fruit and vegetables & $34 \%$ \\
\hline Office supplies & $7 \%$ \\
\hline
\end{tabular}

Source: Analysis of public procurements conducted by the City administration of the City of Belgrade in 2014, Department for Centralized Public Procurement and Procurement Control, (internal document), 2015

The data from Table 1 indicate that prices attained in 2015, by means of centralization of public procurements, are considerably lower than in individual procurements conducted by contracting authorities for the same subjects of procurements in 2014. Positive effects are even more pronounced having in mind that the greatest savings, of $53 \%$, was achieved in services of mobile telephony, and that these savings had the single biggest share in the total savings due to the greatest contract value of approximately EUR 430,000. It is also of significance that this particular procurement was conducted on behalf of 14 contracting authorities which, in turn, adds to the positive effects of centralization. When it comes to the hygiene items, the centralized procurement was conducted on behalf of 35 contracting authorities and the prices were almost halved, since the centralized body purchased in considerably larger (aggregated) quantities relative to what the contracting authorities had individually done in 2014. Even if the prices achieved by centralization of procurements of office supplies were lower by mere $7 \%$, a significant positive effect has nonetheless been achieved, both due to equalizing the prices at which the contracting authorities have been purchasing in the territory of the City and the fact that the procurement was conducted on behalf of as many as 45 contracting authorities, meaning that 45 procurement procedures were substituted by a single one. 
It may be concluded that centralization, in addition to having brought about the equalization of purchase prices, has also achieved yet another effect: owing to the aggregating, that is, "bulk buying", purchase prices got to be reduced in relation to those previously achieved by individual contracting authorities when procuring the goods on their own.

Lastly, it is also of significance to take stock of the effect that centralization of public procurement at the level of the City of Belgrade had on reduction of transaction costs. As underlined above, the first and most prominent effect on reduction of transaction costs is reflected in the substitution of numerous procedures by a single procedure. Therefore, it is important to calculate thus achieved savings in terms of time.

In order to determine the savings, firstly we need to determine how much time, on average, an open procedure takes, quantified in man/hours. The first step in an open procedure, which can be labelled as public procurement planning, is to establish the needs at the annual level; this requires teamwork of several organizational units within given contracting authority and total engagement of employees of 24 man/hours. Upon a completed analysis of needs, there follows a market research, in order to overcome the risk of bounded rationality due to insufficient awareness. Assuming this has to do with a recurrent procurement, repeated year after year, time spent on this type of research amounts to $16 \mathrm{man} /$ hours. The harmonization of the projected needs with the financial plan which, as a rule, entails teamwork of several organizational units, requires an engagement lasting $8 \mathrm{man} / \mathrm{hours}$. The overall engagement for the first, preparatory stage of public procurement is, in total, $48 \mathrm{man} /$ hours or 6 man/days ${ }^{1}$.

The second step is to initiate the public procurement procedure, involving the drafting of detailed technical specifications and verifying the validity of the procurement's estimated value, in order to minimize the risk of bounded rationality in the course of processing gathered information. Assuming this has to do with a standardized procurement, repeated annually, and all has to be done is to adjust the technical specifications to the given year, and that such specifications do not differ significantly from those of the preceding period, the time necessary for these two activities amounts to $8 \mathrm{man} /$ hours. There are also additional 3 man/hours needed to prepare a decision on initiating the procedure and establishing the public procurement panel, totalling in $11 \mathrm{man} / \mathrm{hours}$.

The third step is to prepare the tender documentation, with model contract as its integral part. This is a particularly important step, since good preparation of the tender documentation reduces the risk of bounded rationality and opportunistic behaviour, by means of precise expression of needs so that the bidders get a clear picture of what the contracting authority needs. Its importance also involves anticipation of possible deviations in the stage of implementation of contractual obligations. Having in mind the importance and complexity of these activities, and the fact that all three members of the public procurement panel are involved in the drafting of tender documentation, the time needed for its realization amounts to 9 man/days.

The fourth step is to publish the invitation to bid at the Public Procurement Portal and on the contracting authority's website. This includes the time needed to answer the questions of potential bidders and post relevant answers on the Portal and on the contracting authority's website; it also helps reduce informational asymmetry to the detriment of bidders and adds to their better understanding of the contracting authority's needs and, consequently, helps them prepare better bids. These costs belong to the category of ex ante transaction costs of bounded rationality. Time and efforts invested into this stage enable a greater number of bidders to submit adequate bids, and also are conducive to strengthening the trust and generate a stronger competition. These activities consume $8 \mathrm{man} /$ hours or $1 \mathrm{man} / \mathrm{day}$.

The next three steps are related to the evaluation of submitted bids, in assessing the extent to which they meet the needs of the contracting authority. More specifically, the fifth step is opening the bids and taking minutes on the opening of bids, which requires an engagement of 3 members of the panel for 3 hours each, totalling $9 \mathrm{man} / \mathrm{hours}$. The sixth step is compiling a report on expert evaluation of bids, performed by members of the public procurement panel which, on an average, takes 12 hours, or 36 man/hours, in total since this requires engagement of all three members of the panel. The seventh step is drafting a decision on awarding contract, which requires $3 \mathrm{man} /$ hours. 
The total time necessary to prepare and conduct a public procurement procedure up to the signing of the contract in an open procedure, on average, amounts to 23.5 man/days. We opted to express transaction costs in man/days, rather than to translate them into monetary terms, because of the relatively low cost of labour in Serbia relative to European countries. Otherwise, one might infer that transaction cost in Serbia is low when compared to its counterpart in some of the European countries, for instance in Norway, where the calculations offer that the procurement costs are some EUR 10,000, making it around $4 \%$ of the procurement value (Strand, 2011).

This temporal term (in man/days) in the Belgrade example reflects in a better way an insufficient efficiency in conducting public procurement procedures as well as unnecessarily high transaction costs that ought to be reduced, among other means, by means of centralization of public procurements by applying framework agreements. Having in mind that the Department for Centralized Public Procurement and Procurement Control conducted procedures, on an average, for 19 contracting authorities, the savings in time are obviously significant, knowing that, on an average, 19 procedures requiring $23.5 \mathrm{man} /$ days each, were substituted by one.

Another outcome of the centralization of public procurements from 2015 was an enhanced compliance of the procedures. Out of 35 requests for the protection of rights filed in 2014, the Republic Commission for the Protection of Rights in Public Procurement Procedures adopted 15, which, as a rule, meant that relevant procedures were cancelled and had to be repeated, together will all associated costs and other expenses. Upon the introduction of centralized procurements, regularity of procedures increased so that the procedures conducted in 2015 by the Department ended up with only 4 requests for the protection of rights approved by the Republic Commission, which has considerably decreased the number of procedures that had to be repeated.

\section{Analysis of Budgetary Items for the City of Belgrade}

The focus of this part of the paper lies on the analysis of budgetary items for the City of Belgrade, revenues and proceeds, expenditures and allocations, for 2013, 2014 and 2015, with a view to discern the changes in structure and in time.

On the basis of the analysis of the budget of the City of Belgrade from 2013 through 2015, Figure 1 presents flows in Class 4 - Operating expenditures, Class 5 - Expenditures for non-financial property, and Class 6 - Expenditures for repayment of the principal and for acquisition of financial property. This Graph reveals an increase in the amounts of Class 4 - Operating expenditures and Class 6 - Expenditures for repayment of the principal and for acquisition of financial property, and a decrease in the amount of Class 5 - Expenditures for non-financial property.

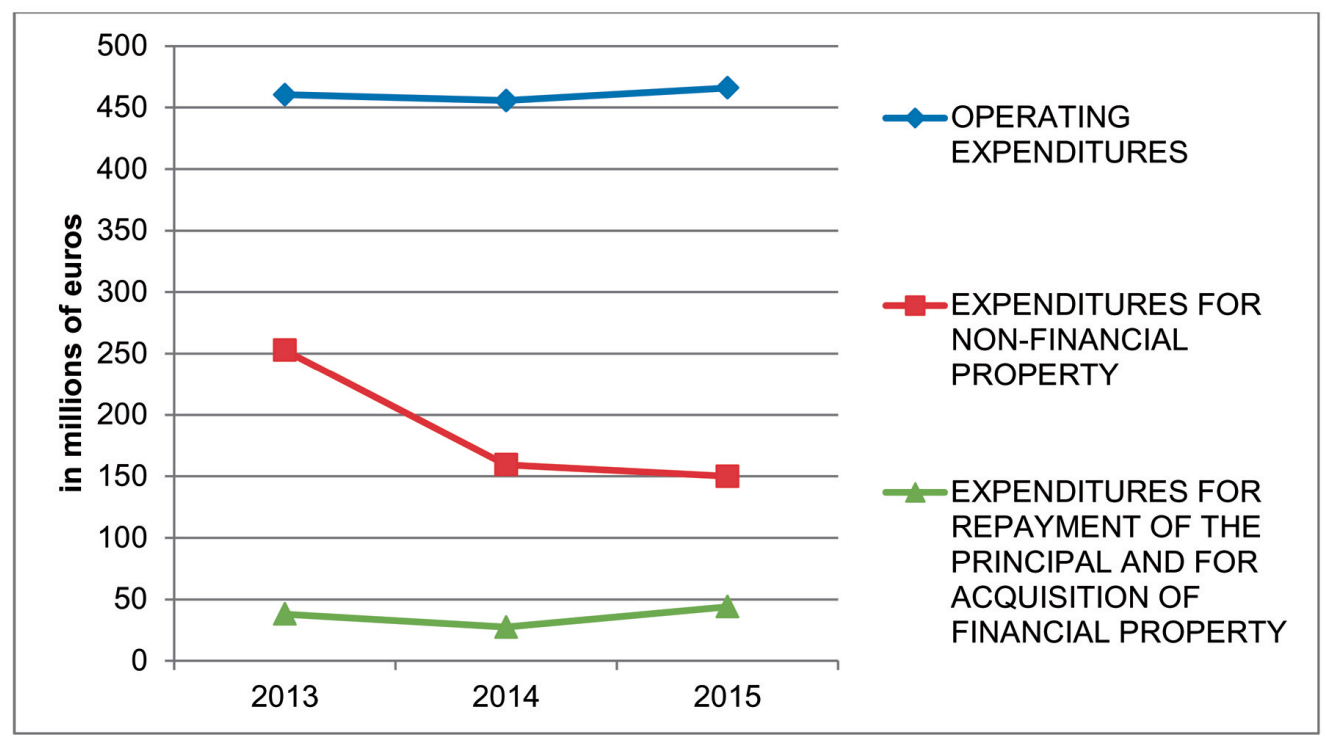

Figure 1: Flows of the key expenditure classes in the City of Belgrade budget, $2013-2015$ Source: Official Gazette of the City of Belgrade, No 65/12, 50/14 and 96/14 Exchange rate: 1 euro = 121,6 RSD 
When viewing the analysis of Classes 4,5 , and 6 in terms of the total amounts, and on the basis of Figure 2 , indicating the flow of total amounts of Classes 4, 5, and 6 of the budget of the City of Belgrade from 2013 through 2015 , one can notice the reduction in the total operating expenditures and expenditures for repayment of the principal and acquisition of financial property within the observed period.

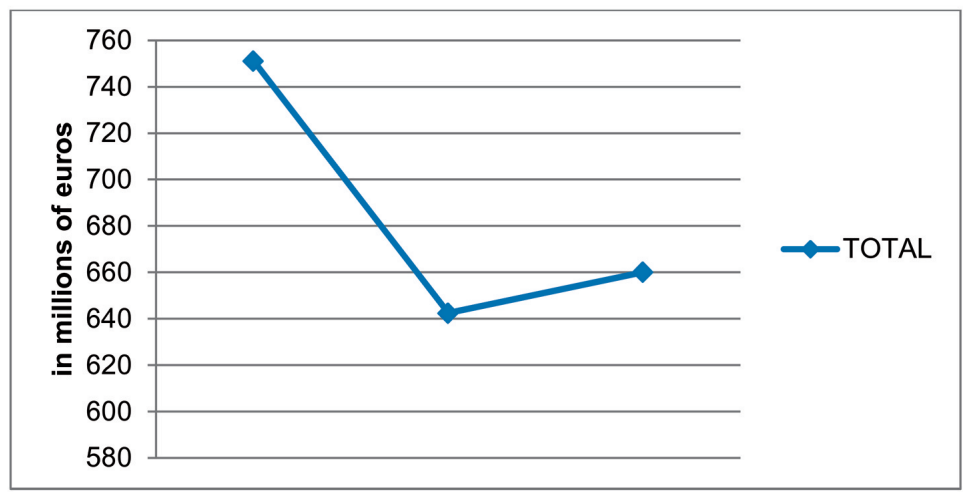

Figure 2: Flows of Classes 4, 5, and 6, 2013 - 2015

Source: Official Gazette of the City of Belgrade, No 65/12, 50/14 and 96/14

Exchange rate: 1 euro $=121,6$ RSD

By observing the flow of operating expenditures in the budget of the City of Belgrade from 2013 through 2015, Figure 3 shows that the largest share, year after year, belongs to the use of services and goods, whereas the smallest share belongs to the reserves.

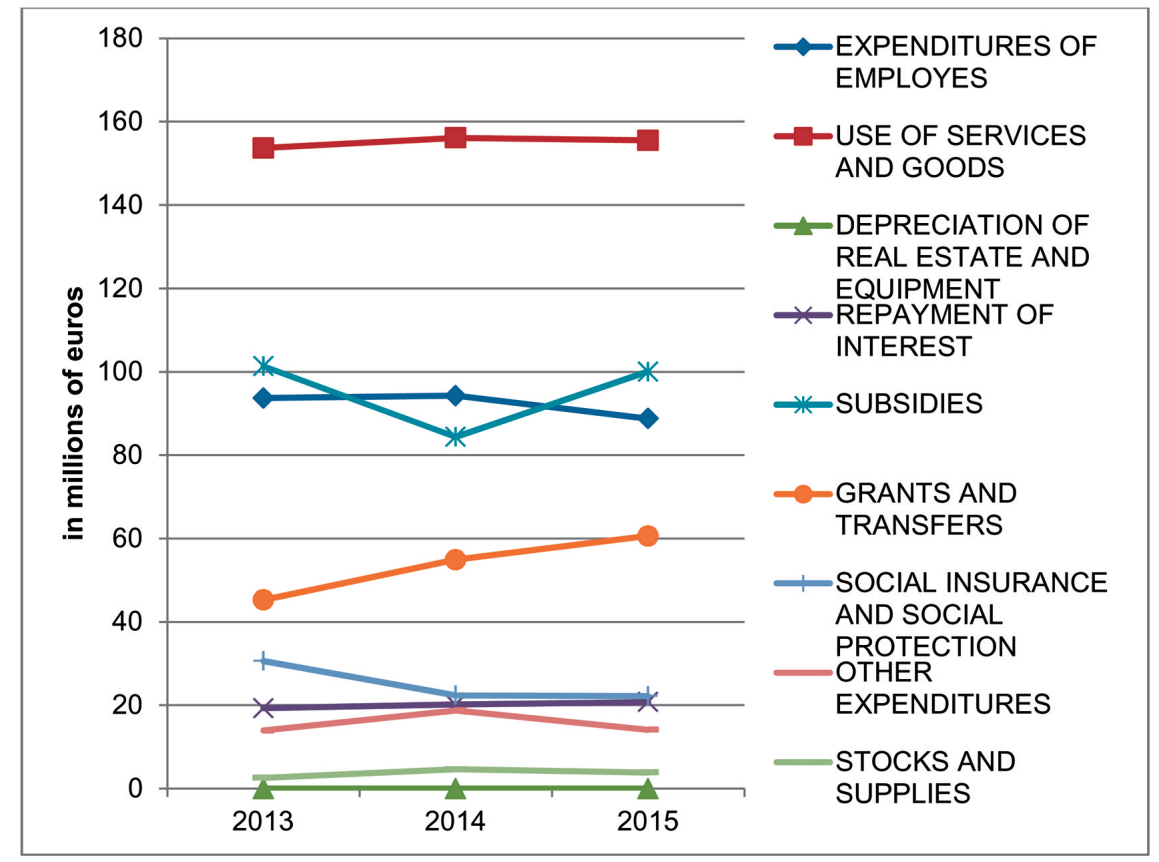

Figure 3: Flows of expenditures within operating expenditures, 2013 - 2015

Source: Official Gazette of the City of Belgrade, No 65/12, 50/14 and 96/14

Exchange rate: 1 euro $=121,6 \mathrm{RSD}$

By observing the flows of types of expenditures for non-financial property in the budget of the City of Belgrade from 2013 through 2015, Figure 4 shows that the largest share, year after year, belongs to the fixed assets (with a downwards trend), whereas the smallest share belongs to the natural assets. 


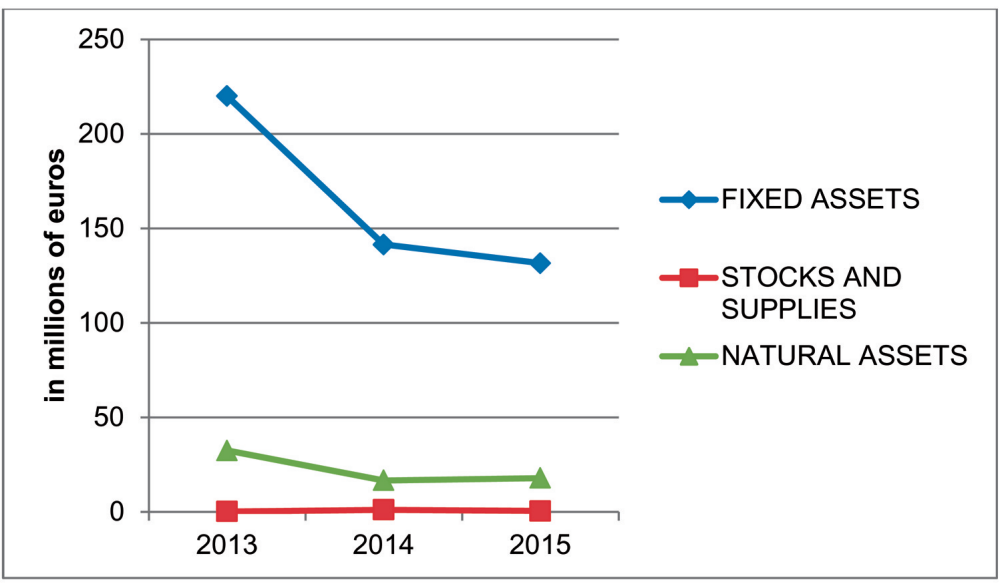

Figure 4: Flows of expenditures for non-financial property in the budget of the City of Belgrade, 2013-2015 Source: Official Gazette of the City of Belgrade, No 65/12, 50/14 and 96/14

Exchange rate: 1 euro $=121,6$ RSD

By presenting the types of expenditures for repayment of the principal and acquisition of financial property in the budget of the City of Belgrade from 2013 through 2015, Figure 5 shows that the largest share, year after year, belongs to the repayment of principal, whereas the acquisition of financial property was only expressed in 2014.

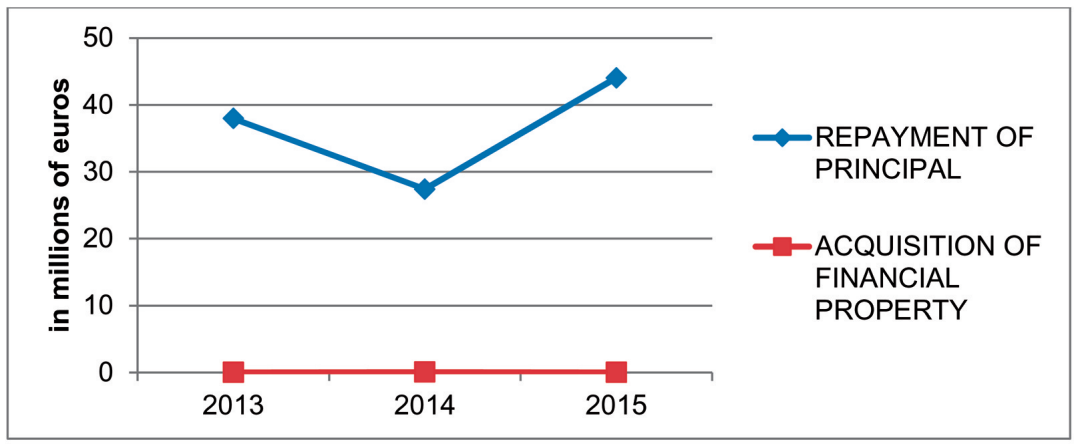

Figure 5: Flows of expenditures within expenditures for repayment of the principal and for acquisition of financial property, $2013-2015$

Source: Official Gazette of the City of Belgrade, No 65/12, 50/14 and 96/14

Exchange rate: 1 euro $=121,6$ RSD

Pursuant to chain indices (for 2014 and 2015), Table 2 presents the flows of Class 4 - Operating expenditures, Class 5 - Expenditures for non-financial property, and Class 6 - Expenditures for repayment of the principal and for acquisition of financial property. One can notice an increase in all chain indices for 2015 relative to chain indices for 2014 (of Class 4 and Class 5 and Class 6 ).

Since the goal of this paper is to take stock of the specific changes in certain positions in the budget of the City of Belgrade for the period from 2013 through 2015, on the basis of chain indices (for 2014 and 2015), Table 2 presents the flow of types of Operating expenditures (Class 4). 
Table 2: Chain indices of operating expenditures, expenditures for non-financial property and expenditures for repayment of the principal and for acquisition of financial property

\begin{tabular}{|l|l|l|l|}
\hline & & Chain indices 2014 & Chain indices 2015 \\
\hline 4 & OPERATING EXPENDITURES & 99 & 102 \\
\hline 5 & $\begin{array}{l}\text { EXPENDITURES FOR NON-FINANCIAL } \\
\text { PROPERTY }\end{array}$ & 63 & 94 \\
\hline & $\begin{array}{l}\text { EXPENDITURES FOR REPAYMENT OF THE } \\
\text { PRINCIPAL AND FOR ACQUISITION OF } \\
\text { FINANCIAL PROPERTY }\end{array}$ & 72 & 160 \\
\hline & TOTAL & 86 & 103 \\
\hline
\end{tabular}

One can notice an increase in chain indices for 2015 relative to 2014 in the Subsidies, and in the Social security and social protection, whereas a decrease in chain indices for 2015 relative to 2014 occurred in: Use of services and goods, Depreciation of real estate and equipment, Repayment of interests, Grants and transfers, Other expenditures, and Reserves.

Table 3: Chain indices for key categories of operating expenditures

\begin{tabular}{|l|l|l|l|}
\hline & & Chain indices 2014 & Chain indices 2015 \\
\hline 42 & USE OF SERVICES AND GOODS & 102 & 100 \\
\hline 43 & $\begin{array}{l}\text { DEPRECIATION OF REAL ESTATE AND } \\
\text { EQUIPMENT }\end{array}$ & 0 & 0 \\
\hline 44 & REPAYMENT OF INTERESTS & 105 & 103 \\
\hline 45 & SUBSIDIES & 83 & 119 \\
\hline 46 & GRANTS AND TRANSFERS & 121 & 110 \\
\hline 47 & SOCIAL SECURITY AND SOCIAL PROTECTION & 73 & 99 \\
\hline 48 & OTHER EXPENSES & 135 & 75 \\
\hline 49 & RESERVES & 179 & 84 \\
\hline
\end{tabular}

With the flows of the total amounts of Class 4 - Operating expenditures, Class 5 - Expenditures for non-financial property, and Class 6 - Expenditures for repayment of the principal and for acquisition of financial property from 2013 through 2015 viewed on the basis of the geometric mean, it was determined that, individually:

$\mathrm{G}_{\text {Class 4- Operating expenditures }}=100.60$

$\mathrm{G}$ Class 5- Expenditures for non-financial property $=77.05$

$\mathrm{G}_{\text {Class 6- Expenditures for repayment of the principal and for acquisition of financial property }}=107.70$.

On the basis of the above calculation, it may be concluded that individually the geometric mean of chain indices reveals that, within the observed period, the amount of operating expenditures has been increasing each year on an average by $0.60 \%$, just like the amount of expenditures for repayment of principal and acquisition of financial property, which has also entailed a regular annual increase, on an average by $7.70 \%$, whereas within the observed period the amount of expenditures for non-financial property has been decreasing each year, on an average by $22.95 \%$ annually.

On the basis of the analysis of the budget of the City of Belgrade from 2013 through 2015, Figure 6 presents the flows of Class 1 - Current revenues, Class 2 - Proceeds from the sale of non-financial property and Class 3 - Proceeds from the sale of financial property and lending. 


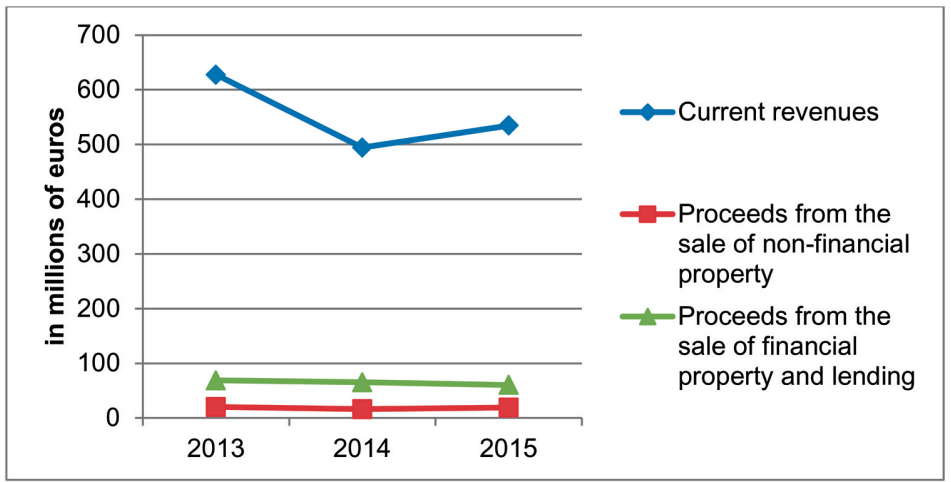

Figure 6: Flows of key categories of revenues, 2013-2016

Source: Official Gazette of the City of Belgrade, No 65/12, 50/14 and 96/14

Exchange rate: 1 euro $=121,6$ RSD

When viewing the analysis of Classes 1, 2 and 3 in terms of the total amounts, and on the basis of Figure 6, indicating the flow of overall Classes 1, 2 and 3 to the budget of the City of Belgrade from 2013 through 2015, one can notice the reduction of the total current revenues and the proceeds from the sale of financial property and lending.

By observing the flow of current revenues to the budget of the City of Belgrade from 2013 through 2015, Figure 7 displays a larger share, year after year, of the Assigned revenues, as opposed to the Source revenues.

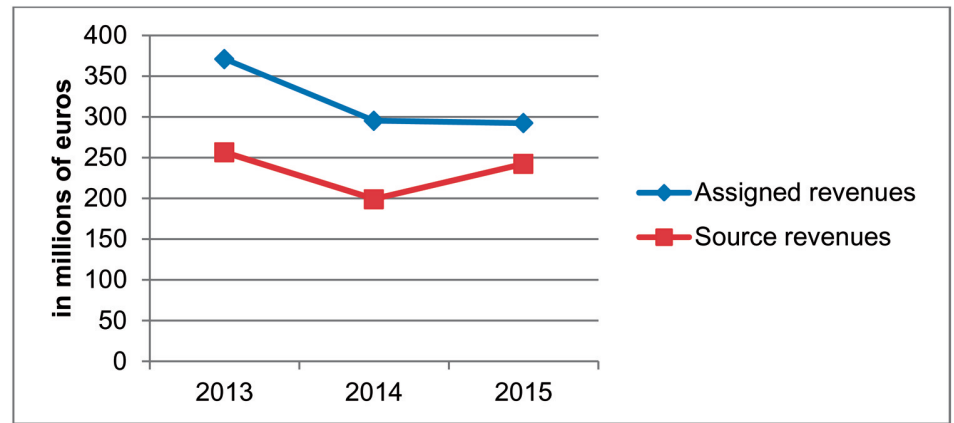

Figure 7: Flows of current revenues, 2013 - 2015

Source: Official Gazette of the City of Belgrade, No 65/12, 50/14 and 96/14

Exchange rate: 1 euro $=121,6$ RSD

By observing the relative changes within Class 1 - Current revenues from 2013 through 2015, in Figure 8 one may notice an increase or a decrease in certain positions within the current revenues to the budget of the City of Belgrade.

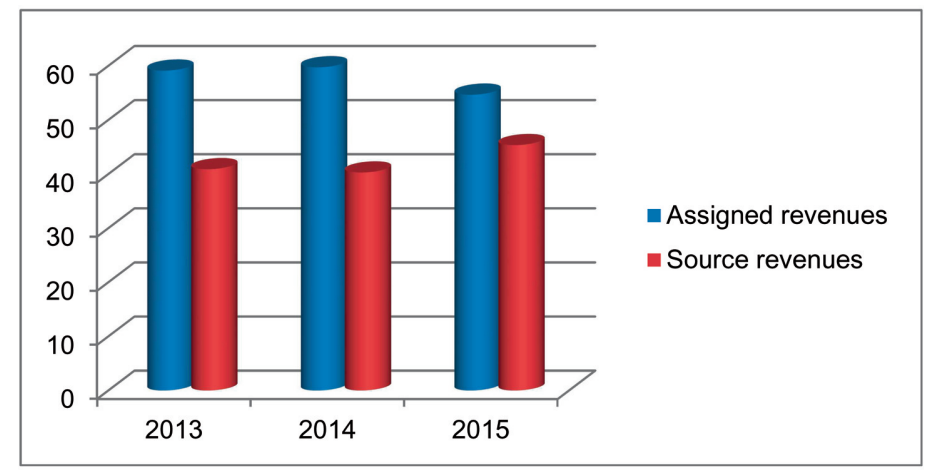

Figure 8: Flows of current revenues, 2013 - 2015, (\%)

Source: Official Gazette of the City of Belgrade, No 65/12, 50/14 and 96/14

Exchange rate: 1 euro $=121,6$ RSD 
By observing the flow of types of proceeds from the sale of non-financial property to the budget of the City of Belgrade from 2013 through 2015, in Figure 9 one may notice a decrease of proceeds in 2014 and an increase in 2015.

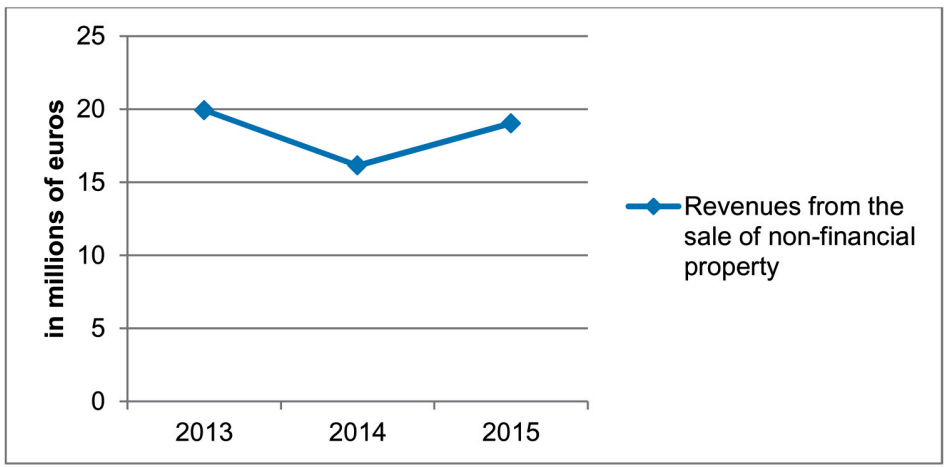

Figure 9: Flows of revenues from the sale of non-financial property, 2013 - 2015 Source: Official Gazette of the City of Belgrade, No 65/12, 50/14 and 96/14

Exchange rate: 1 euro $=121,6$ RSD

By observing the relative changes within Class 2 - Proceeds from the sale of non-financial property from 2013 through 2015, in Figure 10 one may notice an increase or a decrease in certain positions within the proceeds from the sale of non-financial property to the budget of the City of Belgrade.

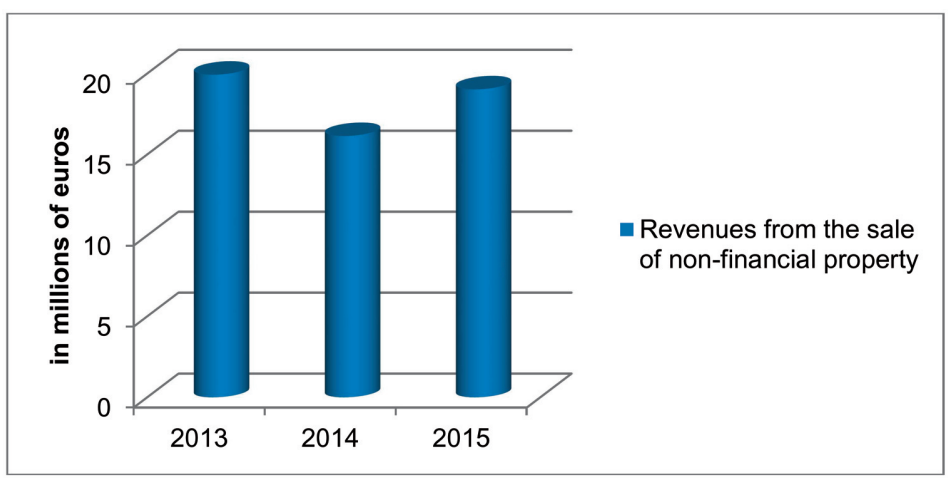

Figure 10: Flows of revenues from the sale of non-financial property, $2013-2015$, (\%) Source: Official Gazette of the City of Belgrade, No 65/12, 50/14 and 96/14

Exchange rate: 1 euro $=121,6$ RSD

By presenting the flow of proceeds from the sale of financial property and lending to the budget of the City of Belgrade from 2013 through 2015, in Figure 11 one may notice a decrease of proceeds by these grounds over the observed period.

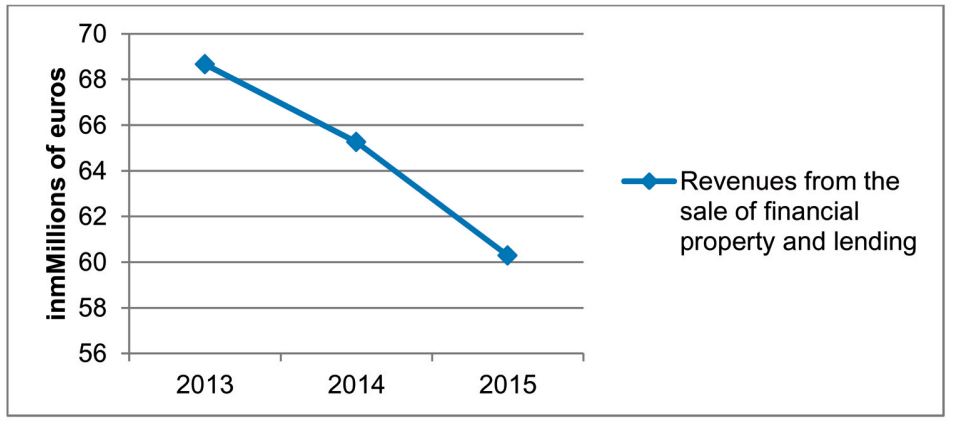

Figure 11: Flows of revenues from the sale of financial property and lending, $2013-2015$ Source: Official Gazette of the City of Belgrade, No 65/12, 50/14 and 96/14 
By observing the relative changes within Class 3 - Proceeds from the sale of financial property and lending from 2013 through 2015, in Figure 12, one may notice the decrease in proceeds over the observed period, too.

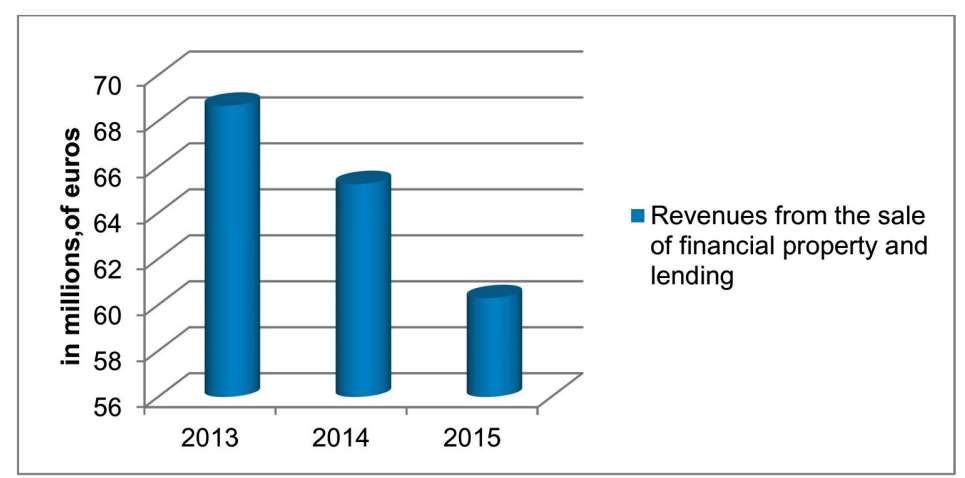

Figure 12: Flows of revenues from the sale of financial property and lending, $2013-2015$, (\%) Source: Official Gazette of the City of Belgrade, No 65/12, 50/14 and 96/14

Exchange rate: 1 euro $=121,6 \mathrm{RSD}$

Pursuant to chain indices (for 2014 and 2015), Table 4 presents the flows of Class 1 - Current revenues, Class 2 - Proceeds from the sale of non-financial property, and Class 3 - Proceeds from the sale of financial property and lending. One can notice an increase in chain indices in 2015 relative to chain indices in 2014 in Class 1 and Class 2, whereas chain indices in Class 3 over the observed period decreased.

Table 4: Chain indices of revenues and proceeds, $(2014,2015)$

\begin{tabular}{|l|l|l|l|l|}
\hline & & Chain indices 2014 & Chain indices 2015 & G (GEOMEAN) \\
\hline 1 & Current revenues & 78.75 & 108.18 & 92.3 \\
\hline 2 & $\begin{array}{l}\text { Proceeds from the sale of } \\
\text { non-financial property }\end{array}$ & 80.99 & 117.86 & 97.7 \\
\hline & $\begin{array}{l}\text { Proceeds from the sale of } \\
\text { financial property and } \\
\text { lending }\end{array}$ & 95.03 & 92.39 & 93.7 \\
\hline
\end{tabular}

With the flows of the total amounts of Class 1 - Current revenues, Class 2 - Proceeds from the sale of nonfinancial property, and Class 3 - Proceeds from the sale of financial property and lending from 2013 through 2015 viewed on the basis of the geometric mean, it was determined that, individually:

$\mathrm{G}$ Class 1 - Current revenues $=92.3$

$\mathrm{G}$ Class 2 - Proceeds from the sale of non-financial property $=97.7$

$\mathrm{G}$ Class 3 - Proceeds from the sale of financial property and lending $=93.7$,

It may be concluded that, individually, the geometric mean of chain indices reveals that, within the observed period, the amount of current revenues has been decreasing each year on an average by $7.7 \%$, just like the value of proceeds from the sale of non-financial property, which has also entailed an annual decrease, on an average by $2.3 \%$, and the value of proceeds from the sale of financial property and lending, which has been decreasing each year, on an average by $6.3 \%$. 
It is of particular importance for the efficient management in the public sector (segment of public procurement) to analyse whether the centralization of public procurements has had any effect on the amount of purchase prices and, if so, to what extent. On the basis of the data used in the study, one may conclude that the centralization has achieved a dual positive effect: on the one hand, it resulted in equalization of purchase prices, and on the other, the consolidation resulted in the reduction of purchase prices relative to the prices previously achieved by individual contracting authorities while conducting their individual procurements.

Another important element in assessing the influence that the centralization of public procurements at the level of the City of Belgrade had on the overall efficiency, is the actual reduction in transaction costs. In this regard, the positive effect is reflected in the substitution of numerous procedures by a single procedure, and this, in turn, results in the savings in time.

When analysing the budgetary items for the City of Belgrade: revenues and proceeds, expenditures and allocations, over the period covered by a temporal sequence (2013-2015), one can observe an increase in the amount of operating expenditures (on an average, an increase by $0.60 \%$ ) and an increase in expenditures for repayment of principal and acquisition of financial property (on an average, an increase by $7.70 \%$ ), and also a decrease in the amount of expenditures for non-financial property (on an average, a decrease by $22.95 \%$ ).

The observed flows in the budgetary items over the observed period may be useful for the planning of the future budgetary expenditures.

\section{REFERENCES}

[1] Analysis of public procurements conducted by the bodies of City administration of the City of Belgrade in 2014, Department for Centralized Public Procurement and Procurement Control of the City of Belgrade, Internal document, 2015

[2] Dyer, J.H.(1997). Effective Interfirm Collaboration: How Firm Minimize Transaction Costs and Maximize Transaction Value, Strategic Management Journal, 18(7), 535-556.

[3] Erridge, A., Fee, R. \& Mcllroy, J. (1998). Public sector quality: political project or legitimate goal?. International Journal of Public Sector Management 11(5): 341-353.

[4] Hennart, J.F. (1993). Explaining the swollen middle: Why most transactions are a mix of "Market" and "Hierarchy". Organization Science, 4(4), 529-547.

^[5] Jaško, O., Čudanov, M., Jevtić, M. \& Krivokapić, J. (2013). Designing Organization, Belgrade: Faculty of Organizational Sciences.

[6] Jaško, O, Jovanović, P. \& Čudanov, M. (2015). Cost Efficiency of Public Procurement at Local level: Chances for Improvement of Local Self-government and Public Enterprises in Serbia. Lex localis.

[7] Jovanović, P. (2015).Centralization of public procurements as a function of decentralization of public administration and of improving the performances of public procurement. (B. Brezovnik ed): Centralization of public procurements at the local level, Lex localis.

[8] McCue, C. P. \& Pitzer, J. T. (2000). Centralized vs. decentralized purchasing: Current trends in governmental procurement practices. Journal of Public Budgeting, Accounting \& Financial Management, 12(3), 400-420.

[9] North, D. C. (1990). Institutions, Institutional Change and Economic Performance. Cambridge, UK: Cambridge University Press.

[10] Schapper, P. R., Malta, J. N. V. \& Gilbert, D. L. (2006). An analytical framework for the management and reform of public procurement. Journal of public procurement, 6(1/2), 1-26.

[11] Self, P. (1993). Government by the Market? The Politics of Public Choice. London, Macmillan.

[12] Strand, I. (2011). Cost and Effectiveness of Public Procurement, PwC, Oslo: Anskaffelseskonferansen DIFI, Oslo.

[13] Williamson, O. E. (1985). The Economic Institutions of Capitalism. New York: Free Press. 


\title{
$1 / 1 / 1 / 1 / 1 / 1 / 1 / 1 / 1 / 1 / 1 / 1 / 1 / 1 / 1 / 1$ abouthe euthor
}

\author{
Snežana Knežević \\ University of Belgrade, Faculty of Organizational Science \\ knezevic.snezana@fon.bg.ac.rs
}

Snežana Knežević was born in 1966 in Pančevo (Jabuka), where she graduated from the secondary school of economics. She graduated from the Faculty of Economics in Belgrade where she also got her MSc degree. She got her PhD degree at the Faculty of Organizational Sciences in Belgrade. The areas of her scientific interest are Finance, Accounting and Environmental protection. She is fluent in French and English. She has published several monographs and papers of scientific and professional orientation in the country and abroad. Currently, she works at the Faculty of Organizational Sciences in Belgrade, Department of Financial Management. She is an associate member of the Scientific Society Of Economists and a member ot the EUMMAS (European Marketing and Management Association).

\section{Predrag Jovanovic \\ Public Procurement Office, Republic of Serbia}

Predrag Jovanovic works as a director of the Public Procurement Office, the Republic of Serbia. At the School of Economics, University of Belgrade, Serbia, he completed his bachelor, master and doctoral studies. His research work, commenced at the Economics institute, was focused on competitiveness, financial markets and public procurement.
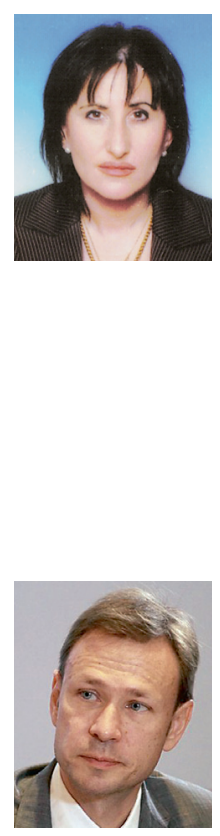

\section{Aleksandra Mitrović \\ University of Kragujevac, Faculty of Hotel Management and Tourism aleksandra.stankovic@kg.ac.rs}

Aleksandra Mitrović, Ph.D., works as a Teaching Assistant at the Faculty of Hotel Management and Tourism in Vrnjačka Banja, University of Kragujevac. She completed her Bachelor Studies in Accounting and Corporate Finance as well as her Master studies at the Faculty of Economics in Kragujevac. She got her PhD degree in 2016. The fields of her scientific and professional interests are related to Accounting and Finance.

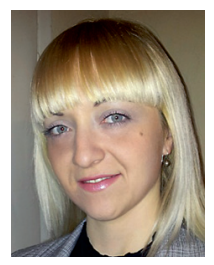

